Літовкіна О. О., к.е.н., старший викладач

Київський національний лінгвістичний університет

м. Київ, Украӥна

DOI: https://doi.org/10.30525/978-9934-26-028-5-33

\title{
УДОСКОНАЛЕННЯ МАРКЕТИНГОВОЇ ПОЛІТИКИ ПІДПРИЕМСТВ В СУЧАСНИХ УМОВАХ
}

В умовах пандемії відбувається стрімке зростання цифровізації багатьох процесів, і цей процес впливає на появу нових маркетингових інструментів на основі використання інформаційних технологій.

Збільшується час, який люди проводять у віртуальному просторі, і маркетологи мають більше можливостей впливу на споживачів через різні засоби комунікації.

На початку розвитку маркетингу зусилля маретологів були спрямовані на просування на ринок та збут уже виготовлених товарів масового споживання, не було спрямованості товару для якоїсь особливої категорії споживачів.

За останні десятиріччя в відбулись величезні зрушення в способах ведення бізнесу, зростання конкуренції на ринках однотипних товарів та їх перевиробництво. I отже зросла необхідність для підприємств використання інновацій, які дозволять зайняти нові ніші на ринках і покращити ринкове положення підприємства.

Маркетинг інновацій передбачає ретельний аналіз ринку, дозволяє визначити сильні та слабкі сторони підприємства, можливості та загрози та визначити такі напрями розвитку інновацій, які дозволять ширше використати потенціал підприємства. Інноваційний маркетинг (нові інструменти та методи маркетингу) передбачає просування нових та вже існуючих товарів у найкращий спосіб.

Н.С. Ілляшенко вважає, що інноваційний маркетинг - це сукупність маркетингу інновацій та маркетингових інновацій, i передбачає виявлення або формування нових потреб споживачів 
та їх задоволення за допомогою інноваційних маркетингових інструментів [1].

Інновації можуть виникати часто в процесі науково-дослідних та дослідницько-конструкторських розробок i обов'язково повинні забезпечуватись маркетинговим супроводом [2].

Говорячи про інновації в маркетингу, маємо на увазі вдосконалення системи роботи 3 клієнтом, методом впровадження інноваційних моделей [1].

Активні в діджитал середовищі компанії, які використовуються віртуальним маркетингом використовують такі маркетингові інструменти:

- Соціальні мережі - Маркетинг впливу, SMM;

- E-mail маркетиг - Сервіси розсилки, адаптивна верстка листів;

- Діджитал маркетинг - Ремаркетинг, ретаргетинг, доповнена реальність, вирощування лідів;

- Контент-маркетинг - Сторітеллінг;

- інструменти пошуку контенту;

- персоналізований контент;

- Пошукові технології - SEO, універсальні та спеціалізовані пошукові системи;

- Змістовний маркетинг - Холістичний маркетинг, продаючий маркетинг, інтелектуальне лідерство; експериментальний маркетинг;

- Мобільний маркетинг - контекстний маркетинг, локальний маркетинг, мобільна оптимізація;

- Big Data та аналітика - прогнозна аналітика, прогресивне профілювання;

- Лідогенерація - CRM системи, Big Data.

Проте наведений перелік не повний, постійно відбувається модифікація існуючих інструментів, i виходять на ринок актуальні новинки.

Перераховані інструменти активно використовуються для стимулювання та розширення збуту. Також швидкими темпами 
зростають обсяги відео контенту в Інтернеті, зокрема на YouTube, де активно використовується та зростає відео маркетинг.

Для країн 3 перехідною економікою, якою зараз є Україна, використання інноваційного маркетингу ще не стало звичним. У розвинених країнах ця концепція працює уже десятиріччя.

Підприємству для обрання правильної інноваційної політики потрібно бути в курсі нововведень, які запроваджені конкурентами. I в цьому велику допомогу надає бенчмаркінг, який дозволяє підприємству проаналізувати свою діяльність, порівнюючи 3 конкурентами та може стати поштовхом для змін та подальших інновацій.

Інноваційний маркетинг також використовує всі засоби, які можуть сприяти успіху на ринку нової продукції.

За ступенем потенціалу інновації поділяють на:

- радикальні інновації - принципово нові вироби і технології. Вони нечисленні і, як правило, передбачають появу нового споживача та / або нового ринку;

- комбінаторні інновації - нове поєднання вже відомих елементів i властивостей. Комбінаторні інновації зазвичай спрямовані на залучення нових груп споживачів та/або освоєння нових ринків;

- модифікуючі інновації - полягають в поліпшенні або доповненні існуючих продуктів. Модифікуючі інновації зазвичай спрямовані на збереження або посилення ринкових позицій підприємства [3, с. 180].

Важливим етапом при впровадженні використання інноваційного маркетингу є знайомство персоналу компанії 3 нововведеннями та його переконання у прибутковості та вигідності нововведень. Також важливо просувати новий продукт на ринку, забезпечуючи комбінацію маркетингу з позиціонуванням продукту, ціноутворенням, комунікацією та рекламою, каналами продажу та багато іншого.

Отже використання інноваційного маркетингу дуже важливе в процесі виведення інновацій на ринок, і в цьому процесі 
тісно переплітаються та поєднуються завдання маркетингу та інновацій.

\section{Література:}

1. Ілляшенко Н.С. Організаційно-економічні засади інноваційного маркетингу промислових підприємств : монографія. Суми : «Вид-во СумДУ», 2011. $192 \mathrm{c}$.

2. Ілляшенко С.М., Рудь М.П. Маркетингові інновації в інноваційній діяльності підприємств України. Ефективна економіка. 2017. № 6.

3. Жариков В.В., Жариков И.А., Однолько В.Г., Евсейчев А.И. Управление инновационными процессами : учебное пособие. Тамбов, 2009. $180 \mathrm{c}$. 